\title{
Adaptowalność w architekturze reagującej na czynniki środowiskowe
}

\section{Adaptability in residential architecture that responds to environmental factors}

\begin{abstract}
Streszczenie
Adaptacja jest procesem w trakcie którego obiekt zmienia swoje właściwości aby dostosować się do zmian zachodzących w środowisku zewnętrznym. Organizmy żywe w celu przetrwania adaptują się w procesie ewolucji - zmiany przystosowawcze dotyczą jednak nie tylko organizmów żywych ale również ich środowiska. Budynki adaptowalne mają za zadanie reagować na zmiany czynników zewnętrznych, są one budynkami raczej przekształcalnymi niż statecznymi. Jakkolwiek idea może wydawać się nowoczesna, to taką nie jest. Zdolność adaptacji za pomocą technologii i materiałów jest znana człowiekowi od dawna. Technologia pozwalająca na adaptację ewoluowała wraz ze zmianami technologicznymi, ekonomicznymi oraz socjologicznymi. Niniejszy artykuł skupia się na przedstawieniu współczesnych domów mieszkalnych adaptowalnych w odniesieniu do czynników środowiskowych, przedstawieniu prototypów oraz omówieniu wybranych komponentów wspomagających tę adaptację.
\end{abstract}

\begin{abstract}
Abstrakt
Adaptation is a process by which an object transform itself to suit the changes in the external environment. Living organisms to survive adapt themselves through evolution - so is the case with residence architecture. Adaptable buildings are intended to respond on changing of external factors, it's rather transformable than static. Although the idea of adaptation may seem innovative, it is not. The ability to adapt by means of building's technology and materials has been known to man for a very long time. It evolved along with technology and changes in economy and sociological fields. This article focuses on explore of the contemporary adaptable houses in relation to external factors, the presentation of prototypes and the discussion of selected building components that supports building's adaptation.
\end{abstract}

Słowa kluczowe: Architektura adaptowalna, architektura responsywna, dom dynamiczny Keywords: Adaptable architecture, responsive architecture, dynamic house

\section{Architektura w środowisku naturalnym}

Otoczenie naturalne nieustannie się zmienia, a zmiany te mogą być zarówno zauważalne w przeciągu krótkiego czasu, jak i długotrwałe, niewidoczne z perspektywy życia jednego człowieka. Jedną z bardziej dynamicznych zauważalnych zmian są warunki pogodowe a także zmiany zachodzące cyklicznie czyli pory roku, dnia i nocy, wpływające na tryb życia każdego organizmu na Ziemii zaczynając od bakterii i innych mikroorganizmów, poprzez florę a skończywszy na organizmach złożonych. Bazując na stwierdzeniu, że środowisko naturalne wpływa na życie między innymi człowieka, można utworzyć schemat wpływów na kształtowanie architektury. Schemat ten jest uporządkowany w oczywisty sposób, obrazuje on wpływ wzajemny środowiska naturalnego na uwarunkowania biologiczne oraz kulturowe, co w konsekwencji oddziałuje na kształtowanie życia człowieka. W efekcie czło-

\section{Architecture in the natural environment}

The natural environment is constantly changing, and these changes can be noticeable in a short time, as well as long-lasting, invisible from the perspective of one's life. One of the most noticeable changes are weather conditions as well as changes occurring cyclically, ie seasons, day and night, affecting the life style of every organism on Earth, starting from bacteria and other microorganisms, through flora and ending with complex organisms. Based on the statement that the natural environment affects the lives of, among others, human, there is possibility to draw a scheme of influences on the shaping of architecture. This scheme is clearly ordered, it illustrates the mutual influence of the natural environment on biological and cultural conditions, which in turn affects the shaping 
wiek poprzez swoje aktywności życiowe oraz w odpowiedzi isk ksztaltuje architekture która ma charakter stały $\mathrm{i}$ jest $w$ założeniu dostosowana do całej gamy zmiennych czynników zewnętrznych. Pierwotne przykłady budynków adaptowalnych bazowały na przemyślanej konstrukcji dostosowanej do warunków klimatycznych oraz wykorzystaniu odpowiednich materiałów. Robert Kronenburg' jako pierwsze przykłady architektury elastycznej (flexible architecture) wskazuje indiańskie tipi o regulowanych otw arch w szczycie i bokch a także namioty bedunów tradycyine domy japoń i nocy na nilo wraz z użciem sztucznego ośmietleni dnia inocy poczynając od ognia, poprzz lampy naftowe a koncząc na pocyna od ogna, popzez Wy wiek odznacza sie szybkin rozwojem

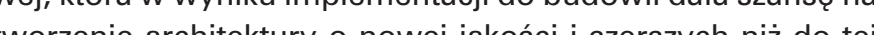
pory możliwościach użytkowych.

2. Responsywne komponenty $w$ architekturze adaptowalnej Według podziału proponowanego przed Branda², budynek składa się z pięciu warstw. Kluczowymi warstwami biorącym udział w mechanizmie budynek - srodowisko zewnętrzne są skin (powłoka), structure (konstrukcja) oraz services (uslugi). Pozostale dwie warstwy - space plan (plan funkcjonalny) oraz stuff (umeblowanie) odpowiadają za funkcjonalnośc planu pomieszczeń. Analizując współczesne budownictwo adaptowalne należy zwrócić uwagę na tendencje architektów do uniezależniania funkcjonowania elewacji od warstw konstrukcji (np. Miramar House ${ }^{3}$, Kiefer Technic Showroom ${ }^{4}$, St Joseph Maternity Clinic $^{5}$, Al Bahar Towers 6 ). Elewacja stała się komponentem w szczególności eksplorowanym i doskonalonym technologicznie w ostatnich latach. Systemy żaluzi lub nawet całych fasad aktywnych maja kluczową role w regulacji mikroklimatu wnetrza dozując odpowiednio doświetlenie środka budynu Idea fasady jako bariery energetycznej zaczeła sie zmieniać pod koniec XX wieku. Zwrócenie uwai na zapotzzebownie energetyczne budynku oraz aspekty Gi na zapotze nakierunkowaty architektów i inży aspekty

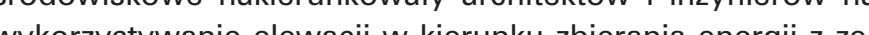
whatrz i kieruncowa jej w miejsca gdzie jest ona potrze zeW tym kor Kin kis Arciecture Winetic Archiecture opisal budynki oraz ich komponenty zdolne do odwracalnych zmian poprzez kinetyke. W podobnym terminie narodzllo się pojecie architekury responsywnej jako odpowiadajacej na potzeby uzy kowników oraz zmiany warunków środowiskowych (Nicolas Negroponte) ${ }^{9}$. W wyniku zmiany postrzegania roli elewacji zaczęły pojawiać się systemy elektronicznego sterowania zacienianiem i wentylacja wewnątrz fasad budynków. Wsród budynków mieszkalnych o aktywnych komponentach, reprezentatywnym przykładem est Sliding House autorstwa londyńskiego biura dRMM. Zasadnicza częsć domu jest statyczna, składająca się z trzech mniejszych budynków (dom, dom gościnny oraz garaż). Kluczowym elementem zapewniającym mechaniczno-elektryczną regulację docieplenia i doświetlenia domu jest elektrycznie sterowana elewacja zewnętrzna przemieszczająca się nad of human life. As a result, human, through his life activities and in response to the intuence of environments, shapes architecture that is permanen and is assumed to be adapted to the whole rang of changing external factors. The original examples of adaptable buildings were based on a well thought-out design adapted to the climatic conditions and the use of appropriate materials. Robert Kronenburg' as the first examples of flexible aropenings in the top and sides, as well as Bedouin tents and tradition a sides, as well as Bedoun pendence from the time of day and night occurred with the use of artificial lighting, starting with the fire, through oil lamps and ending with electricity used from the beginning of the 20th century. The previous century was characterized by the rapid development of digital technology, which as a result of implementation into the building gave an opportunity to create architecture with new quality and wider than ever before the usable capabilities.

\section{Responsive components in adaptable}

architecture

According to the division proposed by $\mathrm{Brand}^{2}$ the building consists of five layers. The main layers involved in the building - external environmen mechanism are skin (shell), structure (construction) and services (HVAC devices, electricity and other). and stuff (furnire are responsibe for the functionality of the floor plan. Analyzing contemporary adaptive construction, attention should be paid to architects' tendencies to make the elevatio function independent of the structure layers (for example Miramar House $^{3}$, Kiefer Technic Showroom $^{4}$. St Joseph Maternity Clinic ${ }^{5}$. Al Bahar Towers $\left.{ }^{6}\right)$. Elevation has become a component in particular explored and technologically improved in recent years. Shutter systems or even entire active facades have a crucial role in regulating the interior microclimate by dispensing the interior of the building properly. The idea of a façade as an energy barrier began to change at the end of the 20th century. Paying attention to the energy demand of the building and environmental aspects have $\mathrm{di}$ rected architects and engineers to use the façade in the direction of collecting energy from the outside and directing it to the place where it is needbook Kinetic Architecture described building and their components capable of reversible changes through kinetics ${ }^{8}$. In the same time, the concept of responsive architecture was born as responding to users' needs and changes in environmental condtions (Nicolas Negroponte) 9 . As a result of changes in the perception of the facade's role, electronic control systems for shading and ventilation inside building facades began to appear. Among the residential buildings with active components, Sliding House stands out by the London dRMM office. The main part of the house is static, consisting of three
1. Warstwy budynku wedtug: Brand [1] rysunek autora / Layers of the building by Brand [1], source: author

stałymi częściami domu. Ponadto dodatkowa, ruchoma elewacja umożliwia zadaszenie odkrytych części rekreacyjnyc budynku: wewnętrznego podwórka oraz tarasu na piętrze. Ruch konstrukcji umozzliwają szyny kolejowe umieszczone w tarasowej podstawie całego kompleksu mieszkalnego. Innym przykładem domu adaptowalnego o samonośnej elewacji jest George House ${ }^{10} \mathrm{w}$ Nowej Zelandii. Dozowanie światła dziennego możliwe jest za pomocą wymiennych paneli elewacyjnych.

Innym, rzadziej stosowanym sposobem adaptacji jest zespoenie konstrukcji z fasadą w jedną, ruchomą część budynku. Zabieg ten niewątpliwie wymaga bardziej zaawansowanch mechanizmów w warstwie Service odpowiadającej za komputerowe wspomaganie zachodzących procesów adaptacyjnych. Sposób ten zastosowali architekci z Irańskiego biura Nextoffice w projekcie Sharifi-ha house ${ }^{11}$. Budynek posiad trzy pomieszczenia funkcjonujace samodzielnie w budynk jako obrotowe komponenty regulujace doświetlen budyn obiektu. Mechanizm adaptacyiny stanowia obrotowe platformy stosowane zazwyczaj w salonach samochodowych. Inna koncep-

\section{2. Schemat ilustrujaccy podział procesów adaptacyjnych
tion process division due to the duration, source: author}

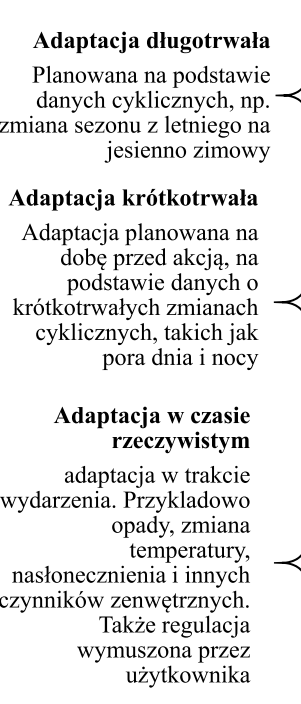

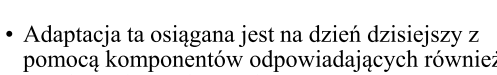
pomoca komponentíw od
za adaptację krótkotrwata

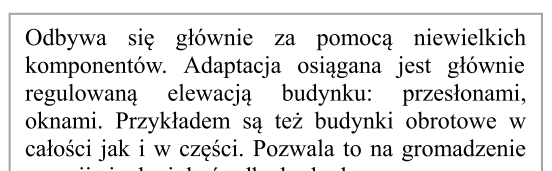

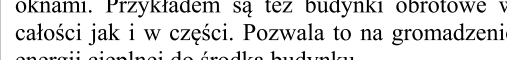

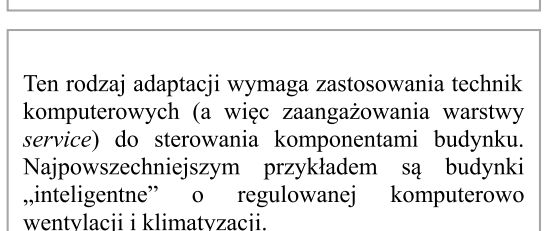

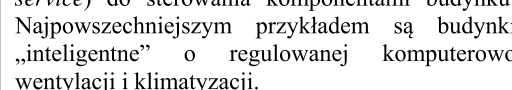

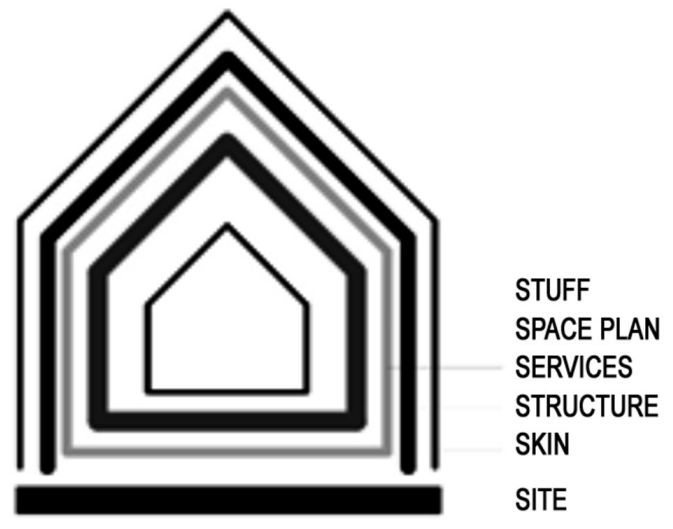

parts. The key element ensuring the mechanical and electrical regulation of insulation and illumihation of the house is the electrically controlled external façade moving over solid parts of the house. Another example of an adaptable house with a self-supporting façade is George House ${ }^{10}$ in New Zealand. Daylight dosing is possible with the help of interchangeable facade panels. Another, less frequently used method of adaptation is to combine the structure with the façade into a whole, movable part of the building. This treatment undoubtedly requires more advanced mechanisms in the service layer responsible for conptar aided adaptation processes. This method was used by architects from the Nextoffice Iranian office in the Sharifi-ha house project. The building has three rooms that function independently in the building as rotating components regulating the lighting of the building. The adaptive mechanism consists of rotary platforms usually ing rooms is characterized by Devon House 11 . Like 
cją ruchomych pomieszczeń charakteryzuje się Devon Hou$\mathrm{se}^{12}$. Budynek podobnie jak Sharifi-ha house beedzie posiada statyczna główna czessć domu, a czesść sypialniana i jadalnia znajdująca sie na piẹtrze sa pomieszczeniami reagujacymi ruchem obrotowym na zmianę pory dnia i strony nasłonecznienia elewacji. Dziś domy o kinetycznych komponentach sa rzadkościa. Chociaż obecnie wśród budynków eko przeważaja systemy biernego pozyskiwania energii, to rozwijanie oraz zastosowanie fasad responsywnych stanowi

niezbędny krok w kierunku poprawy wydajności energetycznej budynków (Loonen, Tr ka, Cóstola, \& Hensen, 2013) ${ }^{13}$.

Analizując przykłady domów adaptowalnych, na podstawie czasu trwania procesu adaptacji można utworzyć podział grupujący typ adaptacji i odpowiadające za nie najczęściej stosowane rodzaje komponentów. Schemat ten ilustruje wyraźne oddzielenie technologii pomiędzy tymi odpowiadającymi za akcje $w$ czasie rzeczywistym (technologia cyfrowa), a elementami kinetycznymi używanymi $w$ adaptacji długo $i$ krótkotrwałej.

3. Domy adaptowalne, reagujące na czynniki środowiskowe Przykład 114: Sharifi-ha house, Nextoffice

Budynek o stosunkowo krótkiej fasadzie wybudowany w Teheranie (Iran). Obiekt zaprojektowany na wąskiej, długiej działce miał za zadanie dostosowywać się do dużej amplitudy temperatur wystepujacych w okresie zimowym i letnim. Budynek posiada 3 kondygnacje naziemne i dwie podziemne. Frontowa fasada obiektu posiada trzy umieszczone kolejno nad soba pomieszczenia zamknięte $w$ formie kubików. Mechanizm adaptowalny pozwala na obrót pomieszczen ○ 90 stopni zmieniając sposób doświetlenia wnętrza. Iran charakteryzuje się wysokimi temperaturami w ciągu lata i łagodnymi zimami. Funkcjonowanie budynku pozwala na osłonięcie wnętrza przed gorącym powietrzem, lub zwiększanie powierzchni okiennych wychodzących na stronę zewnętrzną budynku.

Przykład 2: Lumenhouse ${ }^{15}$

Zadaniem twórców projektu była budowa prototypu domu z prefabrykatów, zasilanego energią sloneczną. Oprócz zastosowania technologii solarnych twórcy poszli o krok dalej tworząc dom przystosowujący się do warunków atmosferycznych. Przeszklone elewacje posiadaja dodatkową, ruchoma przesłone perforowana. W momencie zbyt wysokiej temperatury na zewnatrz budynku, lub gwałtownego jej obniżenia, przesłony zasuwaja s szklana elocie Perforacja przeston ma za zadanie utrzymanie stałego doświetlenia domu Ruch przesłon może być zapocza zawnika zo pony zaztpozyski za pomoca

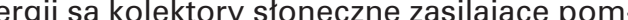
pę grzewczą.

Przykład 3: Dynamic D*House ${ }^{16}$

Główną ideą domu jest przystosowanie do ekstremalnego klimatu panujacego przykładowo w Laponii. Twórca projektu David Grunberg opierając się na matematycznej formule Haberdashera zaprojektował dom posiadający 8 konfigura-
Sharifi-ha house $\mathrm{e}^{12}$, the building will have a static main part of the house, whe the bedroom and dining room located on the first floor are revolving rooms that react to changing the time of day and the side of the sun. Today, houses with kinetic walls are rare. Although currently, among eco-buildings, passive energy generation systems predominate, the deveopment and use of responsive façades is a necessary step towards improving the energy efficiency of Analyzing examples of adaptable houses, 2013$)$ the duration of the adaptation process, a division can be created that groups the type of adaptation and the correspondingly used types of components. This diagram illustrates the clear separation of technologies between those responsible for the actio in real time (digital technology) and the kinetic elements used in long-term and short-term adaptation.

\section{Adaptable houses that responds}

to environmental factors

Example 1: Sharifi-ha house, Nextoffice ${ }^{1 /}$

A building with a relatively short facade located in Tehran (Iran). The object designed on a narrow, long plot was designed to adapt to the high temperature amplitude occurring in winter and sum mer. The bulling has three floors above ground and two underground. The front facade of the building has three consecutively closed spaces allows the rooms to be rotated by 90 degrees, changing the way the interior is illuminated is characterized by high temperatures during the summer and mild winters. The functioning of the building allows you to cover the interior against ho air, or to increase the window area that exits the outside of the building.

Example 2: Lumenhouse

The task of the creators of the project was to build a prototype of a prefabricated house, powered by solar energy. In addition to the use of solar technologies, the developers went a step further by creating a house adapting to weather conditions. Glazed façades have an additional movable perforated shutter. When the temperature outside the building is too high, or if it is rapidly lowered, the iris is closed obscuring the maximum glass elevation. Perforation of the diaphragm is to keep the house permanently lit. The movement of he blinds can be initiated both The solar collectors supplying the heating pump are systems that support energy production.

\section{Example 3: Dynamic D * House}

The main idea of the house is to adapt to the extreme climate prevailing in Lapland, for example. The creator of the project, David Grunberg, based signed a house with 8 configuration configuration of the solid relative to the environment. Each configuration is dedicated to specific outdoor cond- cji ustawień bryły względem otoczenia. Każda z konfiguracji zewnątrz. Zróżnicowana ilość przeszkleń oraz powierzchn ścian zewnętrznych pozwala na całoroczną kontrolę nad efektywnością energetyczną domu. W porach zimowych dom przyjmuje formacje kubika o zminimalizowanej ilości okien i dużą masa termiczna. Wraz ze zbliżająca sie pora letnia budynek otwiera się" stopniowo zwięszając dostep światt do wnętrza.

Przykład 4: Garden House ${ }^{17}$, Caspar Schols

Dom Garden House pełni funkcję domu ogrodowego. Idea projektu było utworzenie budynku do każdych warunków pogodowych, nastroju lub okazyjnych wydarzeń. Dom posiada podwójina powłoke. Powłoka wewnętrzna składa się $z$ podwójnej warstwy szkła mocowanego w drewnianym kratownicowym szkielecie. Powłoka zewnetrzna posiada pełne deskowanie oraz dach z aluminium. Obie elewacje są dzielone na połowę w poprzek osi, $z$ których każda połowa jest przesuwna. Dzięki takiemu rozwiązaniu konstrukcyjnem dom posiada cztery konfiguracje o odmiennych właściwościach. Dom w trybie całkowitego zamknięcia zapewnia ciepłe schronienie. Warstwę izolacyjną stanowią wówczas dwie nasunięte na siebie powłoki. W przypadku zmiennej deszczowej pogody lub wczesnych chłodnych godzin, rozsuwana na boki jest warstwa o pełnych scianach zostawiając na środk szklaną warstwę. Dzięki temu widok na ogród jest dostępny $z$ każdego zakątka domu. Kiedy pogoda jest słoneczna, rozsuwana jest na zewnątrz szklana warstwa powiększając przestrzeń domu. Ostatnią konfiguracją jest całkowite rozsunięcie obu warstw elewacji na boki tworząc powierzchnię tarasowa w środkowej części domu. Budynek ogrzewany jest centralnie ustawionym kominkiem.

Przykład 5: Dom bezpieczny, KWK Promes

Głównym założeniem projektu było spełnienie wymagan inwestora dotyczacych makymalnego poczucia bezan czeństwa w budynku. Bryla budynku jest prostopadtosiencri posiada czesciowo uchoma elewe Dom w swoim paprez presuniecie pelnych scian do czesci wejsciowe paprez presuniecie pe nych scian do czesci wejsciowe budynu odslaniajac przeszkony parter budynku. Dom wykonany jest w technologi żelbetowej, natomiast przesuw częsci elewacyjne wykonane sa jako stalowe kratownice wypelnione welną mineralna. Zastosowanie dużych powierzchni przeszkleń w elewacji pomaga pozyskiwać energię słoneczną w ciągu dnia, co w szczególności jest porządan zima. W porach letnich dom może być osłonięty od promien slonecznych unikając tym sanym przegrzania pomieszczen. W budynku zastosowano dodatkowo hybrydowy system grzewczy oraz rekuperację co sprawiło, że budynek stał sie domem pasywnym.

4. Podsumowanie

Jak pokazują przykłady realizacji domów adaptowalnych w budownictwie mieszkalnym systemy adaptacyjne stosowane są przede wszystkim ze względów funkcjonalnych, tions. Diversified number of glazing and external wall surfaces allows for year-round control over the energy efficiency of the house. In the winter seasons, the house adopts a cubic formation with minimized number of windows and a large thermal mass. With the approaching summer time, the increasing the access of light to the interior.

Example 4: Garden House, Caspar Schols"

The Garden House is a garden house. The idea behind the project was to create a building for all weather conditions, moods or occasional events. The house has a double shell. The inner shell consists of a double layer of glass fixed in a wooden truss framework. The outer shell has full boarding and an aluminum roof. Both elevations are divided in half across the axes, each of which is sliding. Thanks to such a construction solution, the house The house in a fully closed mode provides a warm shelter. The insulation layer is then two overlapped coatings. In the case of a variable rainy weather or early cold hours, the full-wall layer is slid sideways, leaving a glass layer in the middle. Thanks to this, the view of the garden is accessible from every corner of the house. When the weather is sunny, the glass layer is pulled out, enlarging the space of the house. The last configuration is the total separation ing a trace surferin the middle part of the house. The building is heated by a centrally set fireplace.

Example 5: A safe house, KWK Promes

The main assumption of the project was to meet the investor's requirements regarding the building's body is rectangular and has a partially movable façade. The house in its assumption of functioning "opens" to the garden part by moving the full walls to the entrance part of the building evealing the glazed ground floor of the building. is made of reinforced concrete technology, while the sliding façade parts are made as steel trusses filled with mineral wool. The use of large areas of glazing in the façade helps to generate solar energy during the day, which is particuthe sersons, he house can be sheltered from the sun's rays hus avoiding overheating

serid heating a passive house.

Summary

As the examples of adaptable houses are shown in residential construction adaptive systems are used primarily for functional reasons, where human needs are met in the first place (Garden George's house). The second goal, but not the main one in the resulting projects, is to optimize 
gdzie potrzeby człowieka są spełniane na pierwszym miejscu (Garden House, Dom bezpieczny, Lumenhouse, Sliding house, George's house). Drugim celem, ale nie głównym w powstałych projektach jest optymalizacja wydatków energetycznych budynku. Obiektami o systemach dedykowanych do specyficznych wymagań kontekstowych sa Sharifi-ha house oraz D*Haus. Nie sposób nie zauważyć, że te drugie posiadaja znacznie bardziej skomplikowane w budowie $i$ konserwacii elementy adaptacyine, podczas gdy te pierwsze posiadaja proste systemy kinetyczne i posszy te

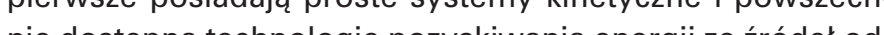
nawialnych.

Pomimo możliwości technologicznych, względy ekonomiczne, kulturowe oraz psych ne, kullu mo ona psychologiczn whiąz przeważą na rzecz budowania standa py prayetych form domón. Czlowiek

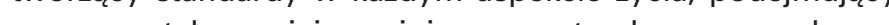
prace $w$ stalym misscu, żyacy w ustandanyzowanych warunkach i dobie masowej produkcj wprowadza zmiany stopniowo z kórych najprostsze do prayjęcia są te niewielkie, nie powodujące rewolucji w sposobie zycia. Nowopowstająca grupa domów adaptowalnych oferuje nieznane dotąd moż liwości osiągania nowych efektów przestrzennych. Można przypuszczać, że inteligentne systemy regulujące funkcjonowanie budynku stanowią podstawę do wprowadzania coraz smielszych działan adaptacyjnych poszerzających możliwości funkcjonowania domu. Doczesne badania wskazują na stymulujący wpływ obiektów interaktywnych na człowieka i społeczeństwo (Urbanowicz, K., Nyka, L.)18, jednakże pytanie o przyszłość architektury adaptowalnej pozostaje otwarta dyskusją

PRZYPISY)

Kronenburg, Robert. Flexible: architecture that responds to change. Laurence King, 2007. How Buildings Learn: What Happens After They're Built, Penguin
2 Brand, S., 1995 . Group US. 1995
${ }_{3} \mathrm{https}: / /$ ww. archdaily.com/499607/house-in-miramar-e-348-arquitectura ${ }^{4}$ https: $/ /$ Www.e-architect.co.uk/austrialkiefer-tecchnic-showroom
${ }_{5}^{5}$ St Joseph Maternity Clinic, Paris | France | AlA Architects I Ingenieurs Associes, Paris ${ }_{6}^{6}$ Informacje na temat budynku dostępne na http://www.ah-global.com/Al-Bahr-

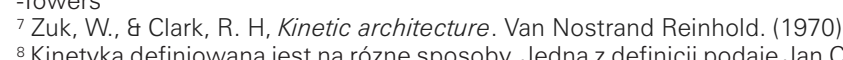

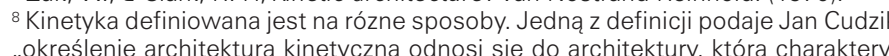
zuje się ró̀̇nego rodzaju ruchem

Negroponte N. The Architecture Machine. MIT Press, 1970.
${ }^{10}$ Opis budynku. zdiecia dostenne na htp.

ide.co.nz/adaptable-house-design/ 11 Zdjecia budynku, plan oraz schemat funkcjonowania dostẹpne na stronie ${ }_{12}$ Devon House zaprojektowata firma D $D^{*}$ Haus której autorstwem jest również 2 miennokstatithy budynek D*Haus,
${ }_{13}$ Loonen, R. C., Tr ka, M., Cóstola, D., \& Hensen, J. L. M. Climate adaptive building shells: State-oft-the-art and future challenges. Renewable and Sustainable Energy Reviews, $25,483-493,2013$.
14 Budynek zaprojektowany przez biuro Nextoffice, wybudowany w 2013 roku w Teheranie. Rzuty i z zdjecia budynku dostepne na http://nextoffice.ir/

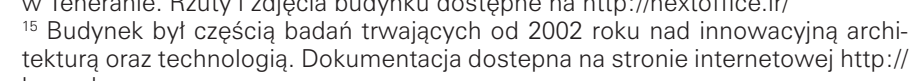
${ }_{16}$ Schemaunat fun

- Schemat funkcjonowania budynku opisany i zwizualizowany na stronie archi-

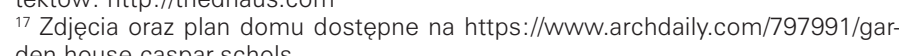
18 Urbanowicz, K., Nyka, L. "Interactive and Media Architecture-From Social En-
counters to City Planning Strategies." Procedia engineering 161 (2016): 1330 -
1337. the energy expenditure of the building. Buildings with systems dedicated to specific contextral tequirements are Sharifi-ha house and $D$ * Haus. It is impossible not to notice that the latter have much more complicated in the construction and maintenance of adaptation elements, while the former have simple kinetic systemsand a comy from avaiable technology for acquiring energy from renewable sources.

Desite technological possibilities, economic, cuin favor of building standardized forms of heves. A man creating standards in every aspect of life taking up a job in a permanent place, living in standardized conditions and the age of mass production introduces changes gradually from which the simplest to accept are those small, not causing a revolution in the way of life. The newly-formed group of adaptable houses offers unknown opportunities to achieve new spatial effects. It can be assumed that intelligent systems regulating the functioning of the building are the basis for introducing more and more bold adaptation activities that expand the possibilities of the house's functioning. Temporal research indicates the stimulating influence of interactive objects on human and society (Urbanowicz, K., Nyka, L." O) However, how will the adaptable architecture look

ENDNOTES change. Laurence King, 2007 .
2 Brand, S., How Buildings

They're Built, Penguin Groug US. 1995. What Happens After
3 https:/lwww.archdaily com $/ 499607$ hose -e-348-arquitectura

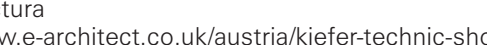
wroom
5 St Joseph Maternity Clinic, Paris | France | AlA Architects Ingenieurs Associés, Paris
6 www.ahr-global.com/Al-Bahr-Towers

7 Zuk, W., \& Clark, R. H. Kinetic architecture. Van Nostrand Reinhold. (1970). R. H. Kin of of of definitions is formulated by Jan Cudzik: the term kinetic
architecture refers to architecture that is characterized by various types of motion 1970 .
10 Building's description at http://www.designguide.co.nz/ 11 More at http://nextoffice.ir/\#!!/project//sharifi-ha-house/ 12 Devon house is designed by $D^{*}$ Haus company. This is house named $D^{*}$ Haus 13 Loonen, R. C., TT ka, M., Cóstola, D., \& Hensen, J. L. M.
Climate adaptive building shells: State-of-the-art and future Climate adaptive building shells: State-of-the-art and future
challenges. Renewable and Sustainable Energy Reviews, 25 .
$483-493.2013$ 483-493, 2013

14 Building designed by Nextoffice, builded in 2013 in Te-
heran. Plans and photos of the building are published on architects' website: http://nextoffice.ilf

作 available on http://lumenhaus.com
and 16 Scheme of the building, plans and photos avaliable on
the website: http://thedhaus.com 17 Plans oand photos of the house avaliable on the website: I/Www.archdaily.com/797991/garden-house-caspar-schols tecture- From Social Encounters to City Planning Strate
gies." Procedia engineering 161 (2016): 1330-1337.
LITERATURA

[1] Brand, S., How Buildings Learn: What Happens After They're Built.

2] Cudzik, J. Kinetyka warchitekturze. Politechnika Gdańska. 2012.
B] Kronenburg, Robert. Flexible: architecture that responds to change.

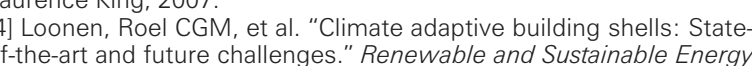
(2013): 483-493. 6] Negroponte N. The Architecture Machine. MIT Press, 1970.
6] Urbanowicz. K., Nyka, L." IIteractive and Media Architecture-Fro social Encounters to city Planning Strategies." Procedia enginee ing 161 (2016): 1330-1337. (1970). Kinetic architecture. Van Nostrand
[7] Zuk, W., \& Clark, R. H. (197).
Reinhold., G

STRONY INTERNETOWE

11] Www.ahr-global. com/Al-Bah-Towers (odstona z dnia 02.01.2018)
[2] https://Www.archdaily.com/797991/garden-house-caspar-schols (2018) ectura (odstona z z dnia 02.01.2018)

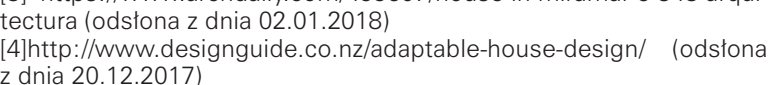
5] https://www.e-architect.co.uk/austria//kiefer-technic-showroom 6] hitt:///lumenhaus.com/about/index.html (odstona z dnia

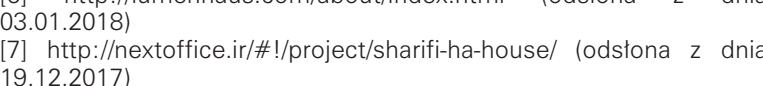
(8] http://theedhaus.com/portfolio/devon-haus/ (odstona z dni

[9] http://thedhaus.com (odstona z dnia 02.01.2018)
REFERENCES

Hi Brand, S., How Buildings Learn: What Happens After They're Buitr.

3) Kronenburg, Robert. Flexiblex: architecture that responds 2012. (4) Loonen, Roel CGM, et al. "Climate adaptive building shells: State-
[at -off-the-art and future challenges." Renewable and Sustainable Energ
Reviews 25 (2013): $483-493$. [5] Negroponte N.'T The Architecture Machine. MIT Press, 1970. [5] Negroponte N." The Architecture Machine. MU Mress,
[6] Urbanowicz, K. Nyka, L. "Interactive and Media Architecture-
From Social Encounters to City Planning Strategies." Procedia engi neering 161 (2016): 1330-1337.
[7] Zuk, W. \& \& Clark, R. H. (1970). Kinetic architecture. Van Nostrand
Reinhold.

WEBSITE SOURCE

[1] Www.ahr-global.com/Al-Bah-Towers (page viewed on 02.01.2018) page viewed on 02.01.2018)

[3] https:I/Tww.archdaily.com

table-house-design/ (page vieWhs. INww.e-architect.co.uk/austria/kiefer-technic-showroo [6] http://lumenhaus.com/about/index.html (page viewed on [7] http:///nextoffice.ir/\#!! project/sharifi-ha-house/ (page viewed on 02.012018 / 1 echaus.com/porttolio/devon-haus/ (page viewed on [9] http://thedhaus.com (page viewed on 02.01.2018) 